\title{
A new bacterial blight of pomegranate caused by Pseudomonas sp. in Maharashtra, India
}

\author{
Smita B. Jagdale ${ }^{1} \cdot$ Mahesh S. Sonawane ${ }^{2} \cdot$ Balu P. Kapadnis $^{1}$ \\ Received: 24 January 2018 / Accepted: 30 July 2018 / Published online: 3 August 2018 \\ (C) Australasian Plant Pathology Society Inc. 2018
}

\begin{abstract}
In the past few decades, pomegranate production in India has greatly suffered from a highly catastrophic bacterial blight disease caused by Xanthomonas axonopodis pv. punicae. Various management strategies have failed to control the disease. During surveys carried out in Maharashtra, India in 2010-2015, an unusual yellow pigmented bacterium was consistently associated with pomegranate showing blight symptoms. Based on morphological, biochemical, 16S rRNA and gyrase B gene sequencing, the bacterium was identified as Pseudomonas sp. Pathogenicity was assessed both by a detached leaf assay method (in vitro) and in pomegranate plantlets (in vivo). To the best of our knowledge, we report Pseudomonas sp. as a cause of new bacterial blight disease of pomegranate in Maharashtra, India in addition to Xanthomonas axonopodis pv. punicae.
\end{abstract}

Keywords Bacterial blight · Pomegranate $\cdot$ Pseudomonas sp. · India

Pomegranate is one of the major cash fruit crops grown in India. The blight disease of pomegranate, when first reported, was known to be caused by Xanthomonas axonopodis pv. punicae (Hingorani and Mehta 1952; Hingorani and Singh 1960). Over the past few decades, bacterial blight has created havoc among pomegranate cultivators in India especially in Maharashtra, Andhra Pradesh and Karnataka states. The disease results in a huge loss (60-80\%) of economy due to destruction of the fruit. Sometimes the bacterial blight results in complete loss of the orchards (Kumar et al. 2009; Mondal and Mani 2009). Current management practices have not been successful in controlling the disease and it is fast spreading throughout the pomegranate cultivating regions, mainly in Maharashtra, India.

A total of 130 samples of infected pomegranate plant parts (leaves, fruits, stems and flowers) were collected from 10 different fields of various pomegranate growing regions of

Electronic supplementary material The online version of this article (https://doi.org/10.1007/s13314-018-0311-8) contains supplementary material, which is available to authorized users.

Balu P. Kapadnis

bpkapadnis@yahoo.com

1 Department of Microbiology, Savitribai Phule Pune University, Pune, Maharashtra 411007, India

2 National Centre for Microbial Resource, National Centre for Cell Science, Pashan, Pune, Maharashtra 411021, India
Maharashtra (Satana - 30, Malegaon - 31, Solapur - 32, Rahuri - 20, and Purandar - 17 samples), India (Supplementary Fig. S1). The infected pomegranate parts viz., leaves, fruits and stems (Supplementary Fig. S2) were disinfected using 2\% sodium hypochlorite followed by thorough washing with distilled water (DW) and instant dip in $75 \%$ ethanol and washed twice with sterile DW. The early disease spots from disinfected leaves, fruits and stems were cut across the spot using a sterile blade and two drops of sterile saline were added at the cut surface to ensure release of the etiological agent in the form of ooze. The suspension from the infected plant parts in the form of ooze was streaked on Nutrient agar (NA) (HiMedia) plates. The plates were incubated at $30 \pm 1{ }^{\circ} \mathrm{C}$ for 2-3 days and observed for the appearance of the bacterial colonies. Colonies from the plates were purified by streaking on nutrient agar plates. The stock cultures were maintained on YDCA agar (Yeast extract $10.0 \mathrm{~g}$; Dextrose $20.0 \mathrm{~g} ; \mathrm{CaCO}_{3} 20.0 \mathrm{~g}$; Agar $20.0 \mathrm{~g}$; pH 7.0 7.2 per litre of distilled water) plates and slants for short-term storage (Supplementary Fig. S3). For long- term storage, 20\% glycerol stocks were kept at $-80^{\circ} \mathrm{C}$.

In all, 83 isolates obtained from different regions of Maharashtra, India, showed yellow colonies on nutrient agar plates after 3 days of incubation at $30^{\circ} \mathrm{C}$. Single colonies were restreaked on nutrient agar plates to check their purity. Initially colonies showed cadmium yellow colour that later darkened to yellow. Isolated colonies when streaked on YDCA medium showed yellow glistening mucoid colonies, which later showed rough morphology when incubated for longer periods 
Fig. 1 Different stage symptoms of the bacterial blight disease on pomegranate leaves caused by isolated strains from pomegranate growing regions of Maharashtra, India. a control leaf; $\mathbf{b}$ initial water soaked bacterial blight spot; c increased number of blight spots; $\mathbf{d}$ more than one spots appeared and coalesce together to form large infected area on leaf surface

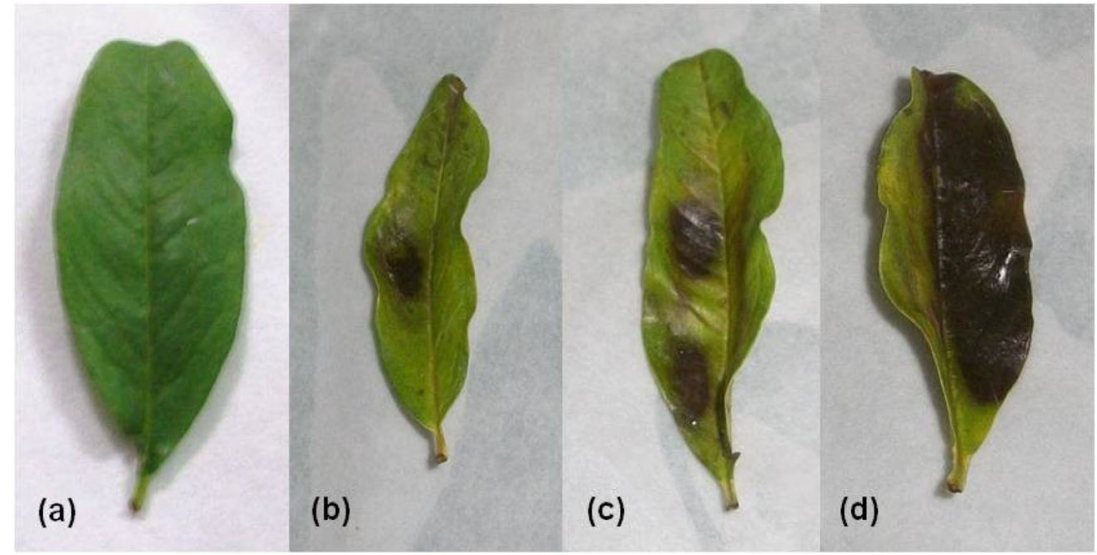

(Supplementary Fig. S3). The cultures grown on YDCA slants even showed growth at $4{ }^{\circ} \mathrm{C}$. The biochemical characterisation suggested that the isolated strains belonged to genus Pseudomonas and Pantoea (Kodama et al. 1985; Schaad 1988; Garrity et al. 2004).

The pathogenicity test for 83 isolates which showed yellow coloured colonies; was performed by detached leaf assay method (Randhawa and Civerolo 1985) with modifications and in vivo on pomegranate plants of 1-3 months old. The healthy pomegranate plants were first washed with sterile DW. These pomegranate plants were then disinfected with $70 \%$ ethanol and then washed thrice with DW to remove traces of ethanol. The plants were then allowed to air dry. For detached leaf assay, 48 isolates were able to produce symptoms of bacterial blight (oily spot) disease on pomegranate but differed in their virulence (Fig. 1). The infection occurred not only on the pinpricked spot of inoculation but also started in the area where the bacterial suspension $\left(10^{8} \mathrm{cfu} / \mathrm{ml}\right)$ was swabbed with the cotton bud, when leaves were incubated at $30{ }^{\circ} \mathrm{C}$ for 10 days. The experiment was repeated thrice with two replicates for each isolate. In addition, the pathogenicity test for the isolated strains was also carried out using a lower dose of $10^{3} \mathrm{cfu} / \mathrm{ml}$. The isolated strains were able to show the symptoms even at a lower dose of inoculum (Supplementary Fig. S4).

The remaining 35 yellow coloured isolates were not pathogenic and belonged to the genera Pantoea, Brevibacillus and Pseudomonas (data not shown). Among these 35 isolates, four Pseudomonas sp. isolates were not phytopathogenic.
Fig. 2 Symptoms of the bacterial blight disease on leaves of pomegranate plantlets caused by isolated strains from pomegranate growing regions of Maharashtra, India. a control plant; b plant showing initial bacterial blight spots on 3rd day; c plant showing increased number of blight spots on 7 th day. The white arrows indicates blight spots

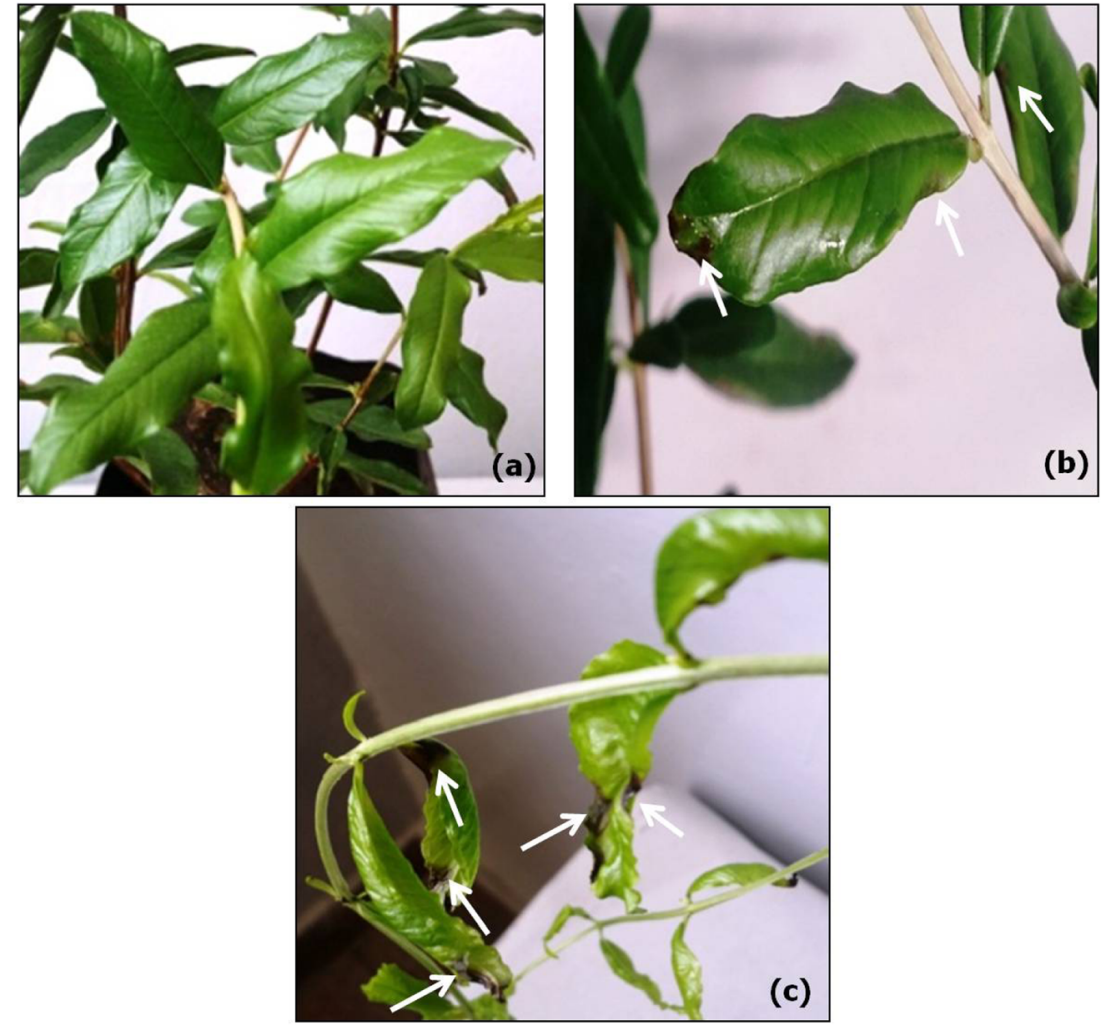


Similarly, for in vivo pathogenicity on pomegranate plants, sterile $1.0 \mathrm{ml}$ syringes were used for pricking the leaves and stems of the pomegranate plants at different locations. Further, the bacterial suspension was sprayed using a hand sprayer onto the syringe-pricked areas mostly then followed by the whole pomegranate plant. A similar procedure was followed with sterile DW, which served as a control. All the pomegranate plants were watered. Then, sterile autoclaving plastic bags were placed over the pomegranate plants and pinned in order to maintain humidity. Minute holes were also created on the sterile plastic bags for the exchange of gases. The pomegranate plants were then subjected to $12 \mathrm{~h}$ light period followed by dark in an incubator room at $30{ }^{\circ} \mathrm{C}$ over a period of 7 days.

It was observed that 48 isolates were able to show bacterial blight symptoms when inoculated on pomegranate plantlets (Fig. 2). The infected leaf part was used for reisolation of the etiological agent. The re-isolated etiological agent were again inoculated and incubated as described above and showed the bacterial blight symptoms, thus confirming the pathogenicity of the isolates. The reisolated strains showed yellow coloured smooth, convex, translucent colonies on nutrient agar plates after 3 days of incubation at $30{ }^{\circ} \mathrm{C}$ and were confirmed by various biochemical and molecular tests. The experiment was repeated thrice with two replicates for each isolates. The morphological and biochemical characteristics (Kodama et al. 1985; Schaad 1988; Garrity et al. 2004) of the isolated pathogenic strains showing bacterial blight symptoms are described in Table 1.

Single representative pathogenic strains isolated from five different regions of Maharashtra, India were selected to carry out further study. The five representative pathogenic strains were deposited in National Centre for Microbial Resource (NCMR), National Centre for Cell Sciences, Pashan, Pune-411,021, Maharashtra, India which is registered by the World Federation for Culture Collections. The accession numbers of the respective strains are shown in Table 2. The bacterial cultures were grown on nutrient agar plates for $24-48 \mathrm{~h}$ at $30{ }^{\circ} \mathrm{C}$. Single colonies were used for isolation of DNA using Qiagen DNA amplification kit (QIAamp® DNA Mini Kit, Cat. No.51304). Total DNA thus obtained was checked on $0.8 \%$ agarose gel and quantified using NanoDrop spectrophotometer (NanoDrop, USA). 16S rRNA gene of the isolates was amplified with universal primers $8 \mathrm{~F}$ (5'- AGA GTT TGA TCC TGG CTC AG - $\left.3^{\prime}\right)$ and $1525 \mathrm{R}\left(5^{\prime}\right.$ - TTC TGC AGT CTA GAA GGA GGT GWT CCA GCC - 3') using GeneAmplifier PCR System 9700 (Perkin Elmer, USA). The polymerase chain reaction (PCR) for $20 \mathrm{ng}$ of DNA comprised mixture of $10 \mathrm{X}$ Taq polymerase buffer, $2 \mathrm{mM}$ dNTPs, $10 \mathrm{pM}$ primers, 1 unit Taq polymerase (Thermo Fisher Scientific). The 16S rRNA gene was amplified by following a protocol of initial denaturation at $94{ }^{\circ} \mathrm{C}$ for $5 \mathrm{~min}, 35$ cycles of denaturation at
Table 1 Biochemical characteristics of pathogenic strains showing bacterial blight symptoms isolated from different regions of Maharashtra, India

\begin{tabular}{|c|c|}
\hline Tests & Results $^{\mathrm{a}}$ \\
\hline Gram's staining & Gram negative rods \\
\hline $\mathrm{KOH}$ string & + \\
\hline Motility & + \\
\hline Catalase & + \\
\hline Oxidase & - \\
\hline Pigment colour (water insoluble) & Yellow \\
\hline King's B medium & No fluorescence \\
\hline Hugh-Leifson /O-F & Oxidative \\
\hline Esculin hydrolysis & - \\
\hline $\mathrm{H}_{2} \mathrm{~S}$ & - \\
\hline $\mathrm{NA}+5 \%$ Glucose & Mucoid colonies \\
\hline $\mathrm{NB}+0.5 \%$ Glucose & Pellicle formed \\
\hline $\mathrm{NA}+6.5 \% \mathrm{NaCl}$ & + \\
\hline Growth at $42{ }^{\circ} \mathrm{C}$ & - \\
\hline Growth on Mac Conkey’s agar & + \\
\hline Growth on SS agar & + \\
\hline $0.1 \% \mathrm{TTZ}$ & + \\
\hline $0.2 \%$ Asparagine medium & + \\
\hline Starch hydrolysis & + \\
\hline Gelatin hydrolysis & + \\
\hline Casein hydrolysis & + \\
\hline Pectin hydrolysis & + \\
\hline Cellulose hydrolysis & + \\
\hline Lipid hydrolysis & + \\
\hline Indole & - \\
\hline Methyl red & + \\
\hline Voges Prauskar & - \\
\hline Simmon's citrate agar & + \\
\hline Nitrate reduction & - \\
\hline Urease & - \\
\hline \multicolumn{2}{|l|}{ LOPAT test } \\
\hline Levan production & - \\
\hline Oxidase & - \\
\hline Pectolytic activity & + \\
\hline Arginine dihydrolase & - \\
\hline Tobacco hypersensitivity & + \\
\hline \multicolumn{2}{|l|}{ Utilization of carbohydrates } \\
\hline Glucose & A \\
\hline Sucrose & A \\
\hline Galactose & A \\
\hline Xylose & A \\
\hline Maltose & A \\
\hline Arabinose & - \\
\hline Lactose & - \\
\hline
\end{tabular}

a ‘+': positive test; '-': negative test; 'A': Acid production 
Table 2 List of representative pathogenic strains isolated from infected pomegranate plant parts from different sampling sites of Maharashtra, India

\begin{tabular}{lllllll}
\hline Isolates & $\begin{array}{l}\text { Sampling sites } \\
\text { in Maharashtra }\end{array}$ & Source & Plant part used & NCMR accession number & $\begin{array}{l}\text { GeneBank accession } \\
\text { number 16S rRNA }\end{array}$ & EZ Taxon match \\
\hline SK 03 & Malegaon & Pomegranate & Leaf & D_FEB_18_055 & KY427437 & Pseudomonas oryzihabitans \\
SK 08 & Satana & Pomegranate & Stem & D_FEB_18_054 & KY427438 & Pseudomonas oryzihabitans \\
SK 10 & Solapur & Pomegranate & Fruit & D_FEB_18_053 & KY427436 & Pseudomonas oryzihabitans \\
SK 13 & Rahuri & Pomegranate & Fruit & D_FEB_18_052 & KY427440 & Pseudomonas oryzihabitans \\
SK 32 & Purandar & Pomegranate & Leaf & D_FEB_18_051 & KY427441 & Pseudomonas oryzihabitans \\
\hline
\end{tabular}

$94{ }^{\circ} \mathrm{C}$ for $1 \mathrm{~min}$, annealing at $55^{\circ} \mathrm{C}$ for $1 \mathrm{~min}$ and extension at $72{ }^{\circ} \mathrm{C}$ for $1 \mathrm{~min}$, final extension at $72{ }^{\circ} \mathrm{C}$ for $10 \mathrm{~min}$ with final hold at $20{ }^{\circ} \mathrm{C}$ for infinity. The PCR products thus obtained were checked on $1.0 \%$ agarose gel and then purified by $\mathrm{PEG}-\mathrm{NaCl}$ (Polyethylene glycol-NaCl) method as described by Salunke et al. (2012).

The gyrase $\mathrm{B}$ gene is one amongst the house keeping genes that are conserved and can be used for identification purpose. A highly virulent isolate SK 10 was selected for gyrase B gene amplification and sequencing. Primers UP-1 (5'- CAY GCN GGN GGN AAR TTY GA -3') and UP-2r (5'- CCR TCN ACR TCN GCR TCN GTC AT -3') illustrated by Yamamoto and Harayama (1995) were used for gyrase B gene amplification. PCR was performed as illustrated above.

Sequencing of the respective amplicons (16S rRNA and gyrase B gene) was carried out on ABI $3730 \times 1$ Automated Sequencer using 'ABI PRISM BigDye Terminator Cycle Sequencing Ready Reaction Kit' (Perkin Elmer Applied Biosystems Division, Foster City, CA). For gyrase B gene, sequencing primers UP-1S 5'- GAA GTC ATC ATG ACC GTT CTG CA -3' and UP-2SR 5'- AGC AGG GTA CGG ATG TGC GAG CC -3' were used as described by Yamamoto and Harayama (1995). Resulting raw sequences were corrected manually using Chromas Pro v 1.34 (Technelysium Pty Ltd., Tewantin QLD, Australia) and sequence homology checked by using EZ Taxon search tool with type strains from database.

First hits obtained along with the other species of Pseudomonas genus were aligned, trimmed and used for the construction of the phylogenetic tree for $16 \mathrm{~S}$ rRNA gene using Neighbour-joining method (Tamura et al. 2011) with bootstrap value more than $50 \%$. The phylogenetic tree constructed for $16 \mathrm{~S}$ rRNA gene showed that the isolated strains form a clade with Pseudomonas oryzihabitans strains while Xanthomonas axonopodis pv. punicae was used as an outgroup as represented in (Fig. 3). All the 16S rRNA gene sequences were deposited in GeneBank and accession numbers were obtained for the representative pathogenic strains isolated from infected pomegranate plant parts from different sampling sites of Maharashtra as shown in Table 2.

Similar results were obtained with the gyrase B sequence of Pseudomonas sp. strain SK 10 which cluster with Pseudomonas oryzihabitans strains while Xanthomonas campestris was an out-group as shown in (Fig. 4). The gyrase B gene sequence of the isolated Pseudomonas sp. SK 10 was deposited in GenBank and the accession number obtained as MF043231.

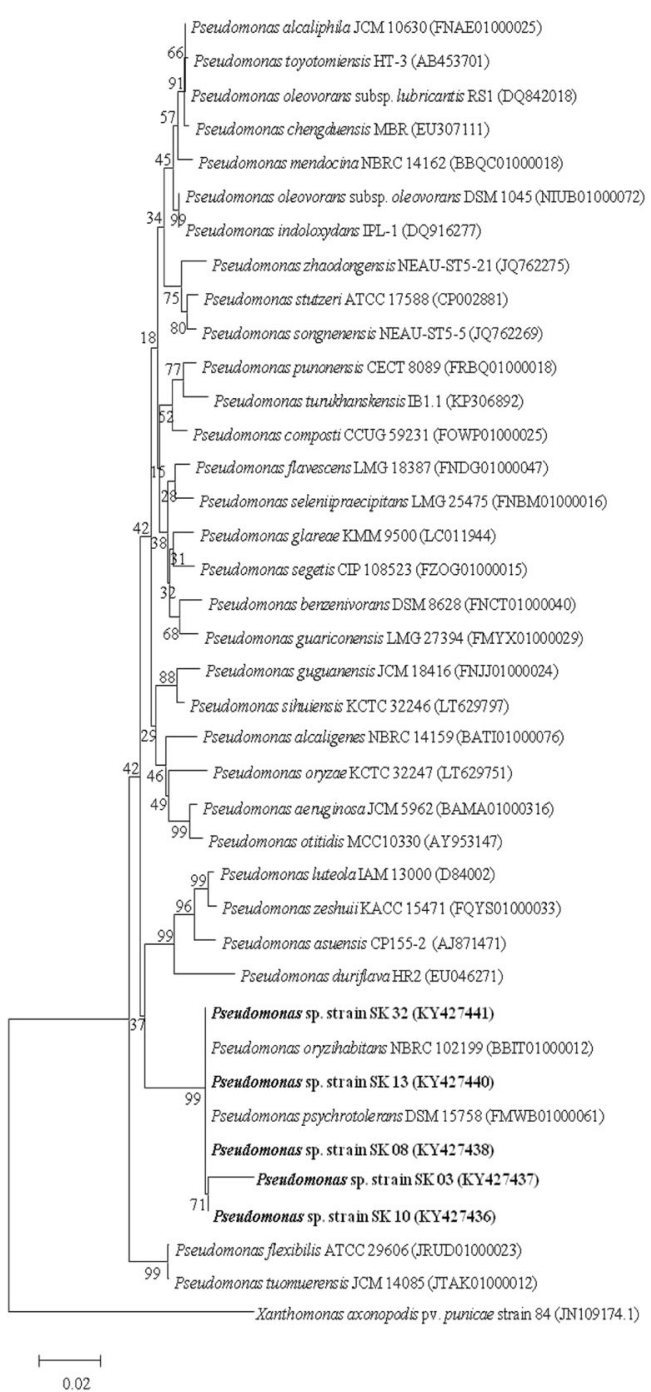

Fig. 3 Phylogenetic tree obtained for 16S rRNA gene sequences by using Neighbour-joining method shows close relationship between the isolated strains and Pseudomonas oryzihabitans strain. Bootstrap percentages are specified on the internal branches while bar, 0.02 is the estimated substitutions per 100 base positions 


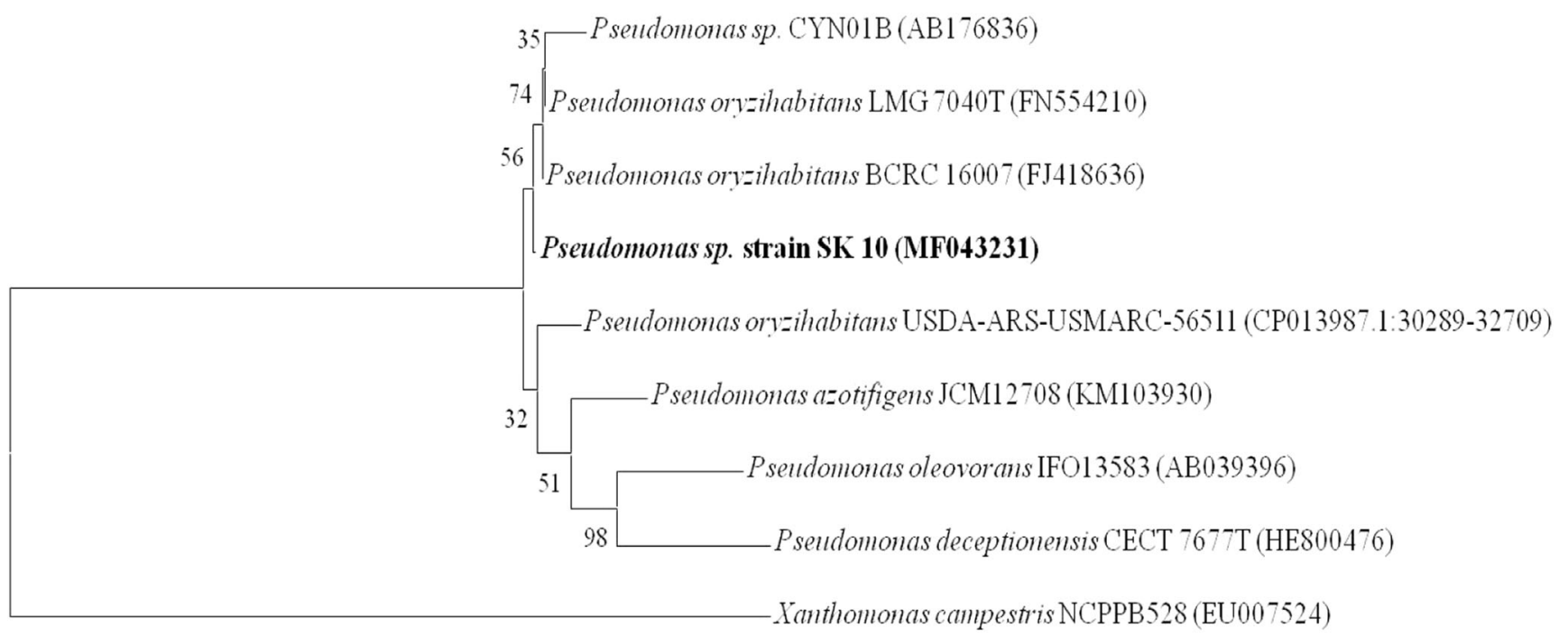

0.1

Fig. 4 Phylogenetic tree obtained for gyrase B gene sequences by using Neighbour-joining method shows close relationship between the isolated strain SK 10 and Pseudomonas oryzihabitans along with other

In the present study, Pseudomonas strains closely related to $P$. oryzihabitans were described as causal agents of a bacterial blight of pomegranate. To date, this disease was ascribed only to Xanthomonas axonopodis pv. punicae (Hingorani and Mehta 1952; Hingorani and Singh 1960). These bacterial strains are characterised by yellow colonies a phenotype that has been already described for a number of Pseudomonas, eg. Pseudomonas oryzihabitans (Kodama et al. 1985), Pseudomonas argentinensis sp. nov.(Peix et al. 2005), Pseudomonas helmanticensis sp. nov. (Ramírez-Bahena et al. 2014), Pseudomonas oryzihabitans (Cottyn et al. 2009; Ruiza et al. 2011; Hardoim et al. 2012). P. oryzihabitans has been already associated with plants, as an endophyte of rice seeds (Cottyn et al. 2009; Ruiza et al. 2011; Hardoim et al. 2012) and in rice and paddy fields (Kodama et al. 1985). Strains from pomegranate were able to induce bacterial blight symptoms when artificially inoculated in detached leaves and plantlets. Riley et al. (2002) reported in detail the plant disease diagnosis including various aspects of complete identification and diagnosis of a particular plant disease and the major factors related to the cause of disease. It may be possible in nature that two different bacteria can show similar symptoms leading to the same disease (Riley et al. 2002). It has been reported that the Xanthomonas axonopodis, Pseudomonas cichorii and few strains of Rhizobiaceae family exhibits typical symptoms causing bacterial blight in eucalyptus (Gonçalves et al. 2008) which supported the result of Pomella et al. (1995) that leaf blight in Eucalyptus grandis was also caused by Pseudomonas cichorii. In addition, walnut blight canker was earlier reported to be caused by Xanthomonas campestris pv. juglandis however, isolation of
Pseudomonas species. Bootstrap percentages are specified on the internal branches while bar, 0.1 is the estimated substitutions per 100 base positions

bacteria from the canker revealed the higher proportion of yellow pigmented bacteria known as Pseudomonas flavescens sp. nov (Hildebrand et al. 1994). In addition, the Pseudomonas sp. isolated in the present study is involved in the progression of bacterial blight disease of pomegranate in Maharashtra, India.

To the best of our knowledge, this is the first report of Pseudomonas sp. as a cause of bacterial blight of pomegranate in Maharashtra, India. As the isolated pathogen, Pseudomonas sp. is able to show the symptoms of the blight disease in pomegranate under laboratory conditions, further investigation of the pathogen is essential and hence is been currently undertaken including the measures to control the blight disease.

Acknowledgements Department of Science and Technology (DST), Government of India provided funds through DST-Women Scientists Scheme-A for carrying out this research work. Authors are grateful to Dr. Yogesh Shouche, Principal Investigator, National Centre for Microbial Resource, National Centre for Cell Science, Pashan, Pune 411021 for his continuous support and guidance in carrying out molecular identification of the isolates. Thanks are due to the University Grants Commission (UGC), India for the award of Emeritus Fellowship to the corresponding author.

\section{References}

Cottyn B, Debode J, Regalado E, Mew TW, Swings J (2009) Phenotypic and genetic diversity of rice seed-associated bacteria and their role in pathogenicity and biological control. J Appl Microbiol 107:885-897

Garrity GM, Bell JA, Lilburn TG (2004) Taxonomic outline of the prokaryotes. Bergey's manual of systematic bacteriology, $2^{\text {nd }}$ edn. Springer, New York, pp 94-247 
Gonçalves RC, Douglas L, Oliveira JR, Maffia LA, Cascardo J, Alfenas AC (2008) Etiology of bacterial leaf blight of eucalyptus in Brazil. Trop Plant Pathol 33:180-188

Hardoim PR, Hardoim CC, Van Overbeek LS, Van Elsas JD (2012) Dynamics of seed-borne rice endophytes on early plant growth stages. PLoS One 7:e30438. https://doi.org/10.1371/journal.pone.0030438

Hildebrand DC, Palleroni NJ, Hendson M, Toth J, Johnson JL (1994) Pseudomonas flavescens sp. nov., isolated from walnut blight cankers. Int J Syst Evol Microbiol 44:410-415

Hingorani MK, Mehta PP (1952) Bacterial leaf spot of pomegranate. Indian Phytopathol 5:55-56

Hingorani MK, Singh NJ (1960) Xanthomonas punicae sp. nov. on Púnica granatum L. Indian J Agr Sci 29:45-48

Kodama K, Kimura N, Komagata K (1985) Two new species of Pseudomonas: P. oryzihabitans isolated from rice paddy and clinical specimens and $P$. luteola isolated from clinical specimens. Int J Syst Evol Microbiol 35:467-474

Kumar R, Shamarao Jahagirdar MR, Yenjerappa ST, Patil HB (2009) Epidemiology and management of bacterial blight of pomegranate caused by Xanthomonas axonopodis pv. punicae. Acta Hortic 818:291-296

Mondal KK, Mani C (2009) ERIC-PCR-generated genomic fingerprints and their relationship with pathogenic variability of Xanthomonas campestris pv. punicae, the incitant of bacterial blight of pomegranate. Curr Microbiol 59:616-620

Peix A, Berge O, Rivas R, Abril A, Velázquez E (2005) Pseudomonas argentinensis sp. nov., a novel yellow pigment-producing bacterial species, isolated from rhizospheric soil in Córdoba, Argentina. Int J Syst Evol Microbiol 55:1107-1112
Pomella AWV, Romeiro RS, Ferreira FA, Oliveira JR (1995) Lesões foliares em viveiro de eucalipto incitadas por uma espécie fluorescente de Pseudomonas. Fitopatol Bras 20:374

Ramírez-Bahena M-H, Cuesta MJ, Flores-Félix JD, Mulas R, Rivas R, Castro-Pinto J et al (2014) Pseudomonas helmanticensis sp. nov., isolated from forest soil. Int J Syst Evol Microbiol 64:2338-2345

Randhawa PS, Civerolo EL (1985) A detached-leaf bioassay for Xanthomonas campestris pv. pruni. Phytopathol 75:1060-1063

Riley MB, Williamson MR, Maloy O (2002) Plant disease diagnosis. The plant health instructor. https://doi.org/10.1094/PHI-I-2002-1021-01

Ruiza D, Agaras B, de Werra P, Wall LG, Valverde C (2011) Characterization and screening of plant probiotic traits of bacteria isolated from rice seeds cultivated in Argentina. J Microbiol 49:902-912

Salunke BK, Salunkhe RC, Dhotre DP, Walujkar SA, Khandagale AB, Chaudhari R, Chandode RK, Ghate HV, Patole MS, Werren JH, Shouche YS (2012) Determination of Wolbachia diversity in butterflies from Western Ghats, India, by a multigene approach. Appl Environ Microbiol 78:4458-4467

Schaad NW (1988) Laboratory guide for identification of plant pathogenic bacteria, 2nd edn. APS press, St. Paul, pp 60-93

Tamura K, Peterson D, Peterson N, Stecher G, Nei M, Kumar S (2011) MEGA5: molecular evolutionary genetics analysis using maximum likelihood, evolutionary distance, and maximum parsimony methods. Mol Biol Evol 28:2731-2739

Yamamoto S, Harayama S (1995) PCR amplification and direct sequencing of gyr B genes with universal primers and their application to the detection and taxonomic analysis of Pseudomonas putida strains. Appl Environ Microbiol 61:1104-1109 